\title{
DEMOCRACIA Y DERECHO NATURAL EN ESTADOS UNIDOS \\ EL PENSAMIENTO DE LOS PADRES FUNDADORES
}

\section{Jorge Ugarte Vial}

El autor analiza el concepto de derecho natural en los padres fundadores de Estados Unidos, y su influencia en el proceso de independencia y en el establecimiento y desarrollo de la democracia en dicho país. Para tales efectos, estudia sus raíces en distintos filósofos y juristas, examina las ideas de ley natural y derechos naturales como fundamentos del orden político en los padres fundadores, y revisa cómo ellas se reflejan en la concepción de una república democrática, basada en la igualdad esencial de todas las personas y en sus derechos naturales a la vida, la libertad y la propiedad. Asimismo, el autor analiza la influencia del derecho natural en distintas instituciones y relevantes debates en la historia de Estados Unidos.

Palabras clave: democracia; derecho natural; Estados Unidos; libertad; padres fundadores.

Jorge UGarte. Abogado. Master en Derecho (LL.M.), Universidad de Columbia, Nueva York; Magíster en Derecho Tributario (c), Universidad Adolfo Ibáñez; Licenciado en Derecho, Pontificia Universidad Católica de Chile.

* El autor agradece especialmente a los profesores Arturo Fontaine Talavera y José Joaquín Ugarte Godoy por su lectura de una versión preliminar de este trabajo.

Estudios Públicos, 119 (invierno 2010). 


\section{Introducción}

$\mathrm{E}$

derecho natural puede definirse en términos amplios como un orden moral universal impreso en la naturaleza misma de los seres humanos, que siendo accesible a todos ellos mediante su sola inteligencia, los guía hacia su fin último; en términos más estrictos, el derecho natural es la parte de dicho orden que se refiere a la justicia. Según el derecho natural, las personas son esencialmente iguales, tienen ciertos derechos inalienables de los que nadie puede privarlas — como la vida, la libertad y la propiedad-, y están sujetas a obligaciones de las que no pueden en modo alguno desvincularse - como la conservación de sí mismas y de la humanidad- El objeto del presente estudio es analizar la concepción del derecho natural en los padres fundadores de Estados Unidos, incluyendo a Jefferson, Hamilton, Adams y Madison, entre otros, y su influencia en el proceso de independencia norteamericana y en el establecimiento y desarrollo de la que llegaría a ser la primera democracia moderna. En el capítulo inicial se analizarán las raíces del derecho natural en los Padres Fundadores, acudiendo a Cicerón, Locke, Montesquieu y Blackstone, autores que ellos estudiaron y admiraron, comparándose las versiones clásica y moderna del derecho natural. En el segundo capítulo se revisará el concepto de derecho natural en los padres fundadores, incluyendo su reconocimiento de la ley natural y de los derechos universales en ella originados. En el tercero, se analizará cómo los padres fundadores concibieron una república democrática basada en la igualdad esencial de todas las personas y en sus derechos naturales a la vida, la libertad y la propiedad, considerando el origen, fines y limitaciones del poder político, con un breve análisis de la influencia de estas ideas en la lucha de Abraham Lincoln contra la esclavitud y de Martin Luther King contra la discriminación racial. Finalmente, se propondrán algunas conclusiones.

\section{Raíces del derecho natural en los padres fundadores}

Observa Lord Acton que, cuando los colonos norteamericanos vieron que su apelación a la ley y a la constitución inglesa no los avalaba en la lucha por sus derechos ante el rey, buscaron un tribunal más alto, y se volvieron de la ley de Inglaterra a la ley natural ${ }^{1}$. En su recurso al derecho natural, los propios padres fundadores expresaron en

${ }^{1}$ Acton (1910), 23. 
diversas oportunidades las fuentes a las cuales acudían: así, comentando el propósito de la Declaración de la Independencia — con su invocación a la ley natural y su reconocimiento de los derechos inalienables de que las personas han sido dotadas por Dios- Thomas Jefferson reconoció la influencia de Aristóteles, Cicerón, Locke y Sidney²; mientras que, para alcanzar un conocimiento más profundo del derecho natural, Alexander Hamilton recomendaba el estudio de Grocio, Pufendorf, Locke, Montesquieu y Burlamaqui ${ }^{3}$. Pasaremos, entonces, a revisar las ideas fundamentales de algunos de estos autores y su influencia en los padres fundadores.

A) El derecho natural clásico: Cicerón

Aunque la concepción clásica del derecho natural sería desarrollada más definitivamente por filósofos cristianos como San Agustín y Santo Tomás de Aquino, sus orígenes se remontan a filósofos griegos como Platón y Aristóteles, y culmina durante la Antigüedad con Cicerón, en quien ya se encuentran sus elementos fundamentales ${ }^{4}$. Según Russell Kirk, los padres fundadores veneraron a Cicerón, pues en él vieron un portavoz de las ideas de libertad en el orden y de ley natu$\mathrm{ral}^{5}$. Efectivamente, Cicerón propone en la República una de las más célebres definiciones de ley natural: "Hay sin duda una ley verdadera, la recta razón congruente con la naturaleza, difundida entre todos, constante, sempiterna; que mandando llama al deber, y prohibiendo aparta del delito; la cual, sin embargo, no ordena ni prohíbe en vano a los buenos, ni mandando o prohibiendo mueve a los malos. No es posible sea dejada sin efecto por otra ley, y no es lícito derogarla en todo ni en ninguna de sus partes; ni podemos de verdad ser desligados de esta ley por el Senado ni por el pueblo; y no hay que buscar expositor o intérprete distinto de ella, ni será una ley en Roma y otra en Atenas; una ahora y otra después: sino que regirá una sola ley a todas las naciones y en todo tiempo, sempiterna e inmutable; y habrá un solo Dios como maestro común y jefe de todos, autor, juzgador y promulgador de esta ley, a la cual quien no obedezca huirá de sí mismo, y renegará de la naturaleza

${ }^{2}$ Dunn (2006), 347.

${ }^{3}$ Hamilton (2008), 51.

${ }^{4}$ Para una síntesis de la concepción clásica de la ley natural, véase Ugarte (2005), 163 y siguientes.

${ }^{5}$ Kirk (2006), 106. 
humana, y por ello sufrirá las mayores penas, incluso si evitare las otras penas que son tenidas por tales" 6 .

La ley tiene para Cicerón distintas dimensiones; primero, ella es un ordenamiento de la inteligencia de Dios: "la ley verdadera y primera, capaz de mandar y prohibir, es la recta razón del supremo Júpiter"7; segundo, es ley el ordenamiento de la inteligencia divina en cuanto deja su huella en la naturaleza: "la ley es la suprema razón, impresa en la naturaleza, que manda aquellas cosas que deben hacerse y prohíbe las contrarias" " y, finalmente, es también ley la inteligencia del hombre, aplicada correctamente al conocimiento de la naturaleza, en cuanto percibe el orden natural ("la recta razón congruente con la naturaleza"), de donde se desprende que éste es cognoscible mediante la sola inteligencia natural, conocimiento que tiene en Cicerón un valor objetivo: "la común inteligencia nos hace evidentes las cosas, y las ha incoado en nuestras almas, de modo que las honestas sean puestas en virtud, y las torpes en los vicios" $"$.

Otro elemento del derecho natural en Cicerón es la fundamental igualdad entre los hombres, que se deduce de la existencia misma de la ley natural como vínculo que une a toda la especie humana ("y regirá una sola ley a todas las naciones") ${ }^{11}$. Cicerón reconoce asimismo la libertad del hombre, quien puede conformarse o no a la ley: cuando adecua sus actos a la ley natural hace bien, pero cuando la contraviene hace mal; así, la libertad humana no excluye la aceptación de la ley, pero para que la ley positiva tenga carácter de tal, debe ser justa, mientras que la injusta no es propiamente ley: Cicerón considera absurdo "estimar que son justas todas las cosas que han sido aprobadas en las instituciones y leyes de los pueblos", pues muchas de ellas son perniciosas y tiránicas,

${ }^{6}$ Cicerón, La República, III, 17. Las citas de Cicerón están tomadas de la edición Lefevre (París, 1823); y su traducción es la de Ugarte (2005).

${ }^{7}$ Cicerón, Las Leyes, II, IV. Esta definición se relaciona con la de ley eterna en Santo Tomás: "la razón de la divina sabiduría que mueve las cosas a su debido fin." (Santo Tomás de Aquino, 1958, 1-2, q. 91, a. 1, c.)

${ }^{8}$ Cicerón, Las Leyes, I. Esta segunda definición se relaciona con la definición de ley natural del filósofo tomista Osvaldo Lira: "la naturaleza del efecto mirada como principio de subordinación a su causa" (citado en Ugarte, 2005, 183)

${ }^{9}$ Esta tercera definición se relaciona con la de ley natural en Santo Tomás: "participación de la ley eterna en la creatura racional." (Santo Tomás de Aquino, 1958, 1-2, q. 91, a. 2, c.)

${ }^{10}$ Cicerón, Las Leyes, c. 16.

${ }^{11}$ D’Entrèves (2004), 26. 
y por ello afirma que "es ley la distinción de lo justo y lo injusto, expresada según aquella antiquísima naturaleza primera de todas las cosas, a la cual se encaminan las leyes de los hombres que castigan a los malos y defienden y cuidan a los buenos"12. Ahora bien, la ley positiva es justa si se adecua a la ley natural, y ésta es manifestación del mismo Dios, por lo que la justicia natural es para Cicerón un valor absoluto, objetivo, que no depende del hombre y es anterior al estado.

\section{B) El derecho natural moderno: Locke}

Para analizar las claves del derecho natural y el poder político en John Locke nos basaremos en su Segundo Tratado del Gobierno Civil, mediante el cual influyó profundamente en los padres fundadores ${ }^{13}$. La concepción del poder político según Locke comienza con el estado en que los hombres se encontrarían originalmente: el estado de naturaleza, esto es, "un estado de perfecta libertad para ordenar sus acciones y disponer de sus posesiones y personas como estimen conveniente, dentro de los límites de la Ley de Naturaleza, sin pedir permiso ni depender de la voluntad de ningún otro hombre"14. Para Locke, la libertad natural - de la cual goza el hombre en este estado- consiste en encontrarse libre de cualquier poder sobre la tierra, salvo la ley natural ${ }^{15}$, y es pre-

${ }^{12}$ Cicerón, Las Leyes, II, V.

${ }^{13}$ En el presente estudio se observa que la influencia de Locke sobre los padres fundadores fue ejercida esencialmente mediante su filosofía política expuesta en el Segundo Tratado del Gobierno Civil, obra inequívocamente iusnaturalista, mientras que su teoría del conocimiento moral expresada en otras obras tuvo para los padres fundadores una influencia poco significativa, si tuvo siquiera alguna. Sin perjuicio de lo anterior, debe considerarse que el estudio comparado de la obra de Locke ha originado importantes discusiones sobre su verdadera concepción del derecho natural: así, analizando algunas de sus obras distintas al Segundo Tratado del Gobierno Civil, Leo Strauss señala que, para Locke, la razón natural es incapaz de conocer la ley natural como ley, y que entonces no puede reconocer una ley natural en sentido estricto (Strauss, 1992); J.B. Schneewind expone las dudas de Locke sobre la capacidad de la razón para descubrir los preceptos de la ley natural, pero asevera que según Locke ello no impide al hombre demostrarlos racionalmente una vez conocidos o confirmados por la revelación cristiana (Schneewind, 1999, 218-219); y Peter Laslett afirma que en el Ensayo sobre el Entendimiento Humano no hay lugar para la ley natural, pero al constatar que el Segundo Tratado del Gobierno Civil es claramente iusnaturalista, el propio Laslett observa que Locke se contradice de una obra en otra, calificándolo como el menos coherente de los grandes filósofos (Locke, 2009, 81-82)

${ }^{14}$ Locke (2009), 269. Locke no considera el estado de naturaleza como una mera hipótesis teórica, e intenta demostrar su existencia histórica.

${ }^{15}$ Locke (2009), 283. 
cisamente este límite en la ley natural lo que la diferencia de la mera licencia ${ }^{16}$. La ley natural es según Locke la propia razón, que gobierna y obliga a todos los hombres, "y que enseña a toda la Humanidad que la consulta, que siendo todos iguales e independientes, ninguno debe dañar a otro en su Vida, Salud, Libertad o Posesiones"17; y, en otro pasaje, coincide con Cicerón señalando que quien se separa de la "recta norma de la razón" se aleja de los principios de la naturaleza humana ${ }^{18}$. Afirma asimismo Locke que las primeras obligaciones del hombre bajo la ley natural son la preservación de la existencia propia y de la humanidad, y que siendo las personas obra y propiedad de Dios, están hechas para durar mientras Él lo disponga ${ }^{19}$. Adicionalmente, la razón es capaz de instruir al hombre "en la Ley por la cual debe gobernarse, y de hacerle saber en qué grado es dejado a la libertad de su propia voluntad" 20 .

Locke sostiene que Dios creó el hombre "bajo fuertes Obligaciones de Necesidad, Conveniencia e Inclinación para conducirse a vivir en sociedad": es decir, considera al hombre un ser sociable, que por ello tiende naturalmente a vivir bajo la sociedad conyugal, la sociedad paterno-filial y la sociedad entre amo y siervo ${ }^{21}$. Pero durante el estado de naturaleza no llega a formar una sociedad política: ésta se forma sólo mediante un contrato que sus integrantes acuerdan voluntariamente, abandonando el estado de naturaleza y acogiéndose a una sociedad política $^{22}$. Por otra parte, Locke señala que el fin de la sociedad política es el bien público, que consiste principalmente en defender y asegurar ciertos derechos naturales que las personas tienen en el estado de naturaleza y que, por tanto, son anteriores al Estado: la vida, la libertad y la propiedad; y que para gozar de esos derechos en paz y tranquilidad, las personas forman la sociedad ${ }^{23}$, facultando a sus autoridades para regir-

${ }^{16}$ Locke (2009), 270.

${ }^{17}$ Locke (2009), 271.

${ }^{18}$ Locke (2009), 273.

${ }^{19}$ Locke (2009), 270-271. Como subraya Richard Ashcraft, la ley natural según Locke no sólo implica el deber de abstenerse de dañar a otros, sino también la obligación positiva de promover la preservación de la humanidad. (Ashcraft, 1999, 239)

${ }^{20}$ Locke (2009), 309.

${ }^{21}$ Locke (2009), 318.

${ }^{22}$ Locke (2009), 331.

${ }^{23}$ Locke (2009), 357-359. Debe tenerse presente que los autores tratados en este estudio generalmente no usan la palabra "Estado", sino más bien las expresiones "sociedad política" (political society), "sociedad civil" (civil society), o "cuerpo político" (body politic), entre otras. 
los mediante leyes dictadas para el bien público, y para cuya ejecución quedan obligadas a prestar su propia ayuda ${ }^{24}$.

Ahora bien, las obligaciones de la ley natural se mantienen bajo la sociedad política, y en muchos casos "se hacen más estrictas, y se les asignan por las Leyes Humanas penas conocidas para exigir su observancia. Entonces, la Ley de Naturaleza permanece como Regla Eterna para todos los hombres, tanto Legisladores como cualesquiera otros" 25 . Adicionalmente, para Locke, como para Cicerón y Santo Tomás, la ley positiva "debe conformarse a la Ley de Naturaleza, es decir, a la Voluntad de Dios, de la cual aquélla es una Declaración; y siendo la principal Ley de Naturaleza la preservación de la Humanidad, ninguna Disposición Humana puede ser buena o válida si la contraviene"26. Por otra parte, el que los hombres formen la sociedad política para preservar sus derechos naturales impone un claro límite al poder estatal: "no puede suponerse que ellos hubieran intentado, de tener poder para hacerlo, dar a una o más personas un Poder absoluto y Arbitrario sobre sus Personas y Propiedades, y depositar en las manos de los Magistrados fuerza para ejecutar arbitrariamente sobre ellos su Voluntad ilimitada"27. Así, el concepto de contrato social de Locke es substancialmente distinto al de Hobbes y Rousseau: para Hobbes, por el pacto social las personas confieren todo su poder y fortaleza al soberano, conformando una república de poder ilimitado ${ }^{28}$, mientras que, para Rousseau, el contrato social implica la alienación total de los individuos y sus derechos en favor de la comunidad, que se expresa mediante la voluntad general ${ }^{29}$.

Locke es partidario del gobierno representativo, pues en él las leyes positivas son sancionadas por legisladores elegidos por consentimiento del pueblo, elemento que considera de la esencia de la ley ${ }^{30}$; y como el poder legislativo se origina por consentimiento de las personas, sus poderes no pueden exceder los que ellas tenían en el estado de naturaleza, "porque ninguna persona puede transferir a otra más poder del que tiene en sí misma, y ninguna persona tiene un absoluto y Arbitrario Poder sobre sí misma, ni sobre ninguna otra, para destruir

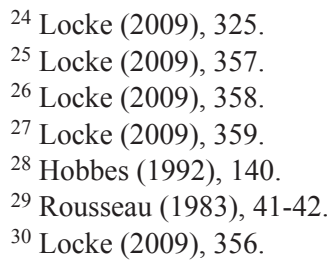


su propia Vida, ni para quitar sus Vidas o Propiedades a otros"31. Mediante el contrato social, las personas se someten a las decisiones de la mayoría ${ }^{32}$; sin embargo, ésta es responsable de los derechos cuya protección las personas le han confiado. Por otra parte, la tiranía puede darse en cualquier clase de gobierno, sin importar si ésta descansa en las manos de una o muchas personas ${ }^{33}$ : lo relevante para calificar un gobierno de tiránico no es quiénes o cuántos lo ejercen, sino si está encaminado a preservar el bien general y los derechos naturales de las personas. Es tan importante para Locke que el gobierno cumpla con sus fines propios, que reconoce al pueblo el derecho de rebelión contra el gobierno ilimitado: cuando éste abusa de sus facultades, el poder "vuelve al Pueblo, quien tiene un Derecho a recuperar su Libertad original, y, mediante el Establecimiento de un nuevo Poder Legislativo, según estime conveniente, a disponer lo necesario para su propia Seguridad y Protección, que es el fin para el cual se ha constituido la Sociedad"34.

\section{C) El derecho natural en Montesquieu y Blackstone}

Las doctrinas políticas de Montesquieu influyeron profundamente en los padres fundadores, particularmente su preferencia por el gobierno constitucional, limitado, con separación de poderes y contrapesos recíprocos. Aunque Montesquieu se esforzó más bien en desentrañar la naturaleza política de las leyes, dedicó también algunas páginas al derecho natural que reforzaron las convicciones de los padres fundadores ${ }^{35}$. Según Montesquieu, las leyes son ciertas relaciones derivadas de la naturaleza misma de las cosas: todos los seres tienen sus leyes, incluyendo a Dios, las cosas materiales y los hombres. Para Montesquieu, existe una razón originaria creadora del universo, y las leyes son las relaciones entre ella y los distintos seres, y de los diversos seres entre sí: "Dios se relaciona con el Universo en cuanto es su creador y su conservador. Las leyes según las cuales lo creó son las mismas por las que lo conserva. Obra conforme a estas leyes porque las conoce; las conoce porque las ha hecho y las ha hecho porque tienen relación con su sabiduría y

\footnotetext{
${ }^{31}$ Locke (2009), 357.

${ }^{32}$ Locke (2009), 331.

${ }^{33}$ Locke (2009), 400.

${ }^{34}$ Locke (2009), 412-413.

${ }^{35}$ Véase, por ejemplo, Hamilton (2008), 51.
} 
poder"36. Por su parte, las leyes positivas son la propia razón humana en cuanto gobierna a todos los pueblos ${ }^{37}$. Para Montesquieu - como para Cicerón y Locke - existe una justicia natural anterior al Estado, y las leyes positivas deben conformarse a ella: "decir que sólo lo que ordenan o prohíben las leyes positivas es justo o injusto, es tanto como decir que antes de que se trazara círculo alguno no eran iguales todos sus radios. Hay que reconocer, por tanto, la existencia de relaciones de equidad anteriores a la ley positiva que las establece"38. Las leyes positivas tienen en Montesquieu una relevante función social: el hombre, no obstante haber nacido para vivir en sociedad, podría olvidarse de los demás, por lo que "los legisladores le hacen volver a la senda de sus deberes por medio de las leyes políticas y civiles"39.

Las ideas de William Blackstone, considerado el jurista más importante en la historia del common law, ejercieron también substancial influencia sobre los padres fundadores, condensando equilibradamente elementos del derecho natural clásico según Cicerón y del moderno según Locke. Para Blackstone, la ley es una regla de conducta "aplicada indiscriminadamente a toda clase de acción, sea animada o inanimada, racional o irracional": el concepto de ley es, entonces, analógico, pues hay leyes inmutables tanto para las cosas materiales (como las del movimiento, la gravitación, la óptica o la mecánica) como para el hombre (su ley natural). Ahora bien, la ley es "prescrita por un superior, y el inferior está obligado a obedecerla": este superior es Dios, que al formar las criaturas les imprime principios vinculantes, y en cuanto éstas respetan sus leyes, continúan en la perfección y responden al fin para el cual fueron creadas: "así como Dios, cuando creó la materia, y la dotó de los principios de la movilidad, estableció ciertas reglas para la dirección perpetua de aquel movimiento; así, cuando creó al hombre, lo dotó de libre albedrío para conducirse en todos los aspectos de su vida, estableció ciertas leyes inmutables de la naturaleza humana, por las cuales el libre albedrío es en cierto grado regulado y restringido, y le dio también la facultad de la razón para descubrir el sentido de aquellas leyes"40.

Para Blackstone - como para Montesquieu- existen relaciones de justicia inscritas en la naturaleza y anteriores a cualquier ley

\footnotetext{
${ }^{36}$ Montesquieu (1972), 52.

${ }^{37}$ Montesquieu (1972), 54.

${ }^{38}$ Montesquieu (1972), 53.

${ }^{39}$ Montesquieu (1972), 52.

${ }^{40}$ Blackstone (2002), 38-39.
} 
positiva: "estas son las eternas, inmutables leyes del bien y el mal, a las cuales el Creador mismo se conforma en todas sus disposiciones", incluyendo las reglas - acuñadas por Justiniano- de vivir honestamente, no perjudicar a nadie, y dar a cada uno lo que le corresponde; pero como ellas constituyen preceptos generales, su aplicación por cada individuo requiere de la razón, cuyo oficio es descubrir "lo que las leyes de la naturaleza mandan en cada circunstancia de la vida, mediante la consideración de qué método tenderá más efectivamente a nuestra propia substancial felicidad"41. Las leyes positivas deben adecuarse a la ley natural, y su principal objeto es mandar que se haga lo correcto y prohibir lo incorrecto ${ }^{42}$, protegiendo a los individuos "en el goce de aquellos derechos absolutos que les fueron conferidos por las inmutables leyes de la naturaleza" ${ }^{43}$. Que tales derechos sean absolutos no significa que sean ilimitados, sino erga omnes; por eso, refiriéndose al derecho a la vida, Blackstone señala que nadie tiene autoridad para disponer de ella, ni siquiera su titular, pues se trata del don inmediato de Dios ${ }^{44}$. Particular interés tiene en Blackstone la relación entre ley y libertad: cuando las leyes son elaboradas prudentemente, "no son en modo alguno destructoras, sino introductoras de la libertad; porque (como Locke ha observado correctamente) donde no hay ley, no hay libertad"45. Finalmente, Blackstone rechaza la existencia del estado de naturaleza y del contrato social, acercándose a una visión aristotélica en que la sociedad política se forma progresivamente como consecuencia de la debilidad e imperfección de la humanidad, lo que la hace necesaria y constituye su fundamento natural ${ }^{46}$.

D) Comparación del derecho natural clásico y moderno

Distintos comentaristas han distinguido el derecho natural clásico del moderno: el clásico habría surgido en la Antigüedad, prolongándose durante la Edad Media, y sus principales exponentes serían Cicerón y Santo Tomás; mientras que el moderno habría nacido en la Europa

\footnotetext{
${ }^{41}$ Blackstone (2002), 40-41.

${ }^{42}$ Blackstone (2002), 118.

${ }^{43}$ Blackstone (2002), 120.

${ }^{44}$ Blackstone (2002), 129.

${ }^{45}$ Blackstone (2002), 122.

${ }^{46}$ Blackstone (2002), 47.
} 
del siglo XVII, y sus primeros representantes serían Grocio, Hobbes y Locke $^{47}$.

D'Entrèves considera que las principales características del derecho natural moderno, por oposición al clásico, son el racionalismo, el individualismo y el radicalismo. El racionalismo se expresaría en que la sola evidencia de la razón permitiría conocer la ley natural con una certeza semejante a la de las ciencias exactas, originando un sistema de normas autosuficiente e independiente de presupuestos teológicos, que dejaría a Dios en segundo plano ${ }^{48}$. Pero aquí debe a mi juicio distinguirse: para el derecho natural clásico, la sola razón basta para conocer la ley natural, independientemente de consideraciones teológicas, como lo demuestran los escritos de Aristóteles y Cicerón, que no se basan en revelación sobrenatural alguna. Por otra parte, aunque puede calificarse de racionalistas a algunos iusnaturalistas modernos, ello no parece aplicable a autores como Locke, Montesquieu y Blackstone, que nunca pretendieron convertir el derecho natural en un sistema matemático autosuficiente; para ellos, la evidencia de la ley natural no impide fundar ésta en Dios, pues se trata de planos distintos: la evidencia de la ley natural alude a cómo ésta se conoce, mientras que Dios constituye su fundamento metafísico, racionalmente cognoscible; además, para autores como Locke y Blackstone, la razón natural está en perfecta armonía con la verdad revelada, y por eso las citan permanentemente como complementarias.

Para D'Entrèves, el individualismo del derecho natural moderno se reflejaría en la concepción del contrato social, en que el estado o sociedad política se forma por acuerdo voluntario de los individuos ${ }^{49}$. Pero, en mi opinión, es necesario matizar, al menos respecto de los autores revisados en este estudio: no obstante creer en el contrato social, Locke considera que el hombre tiende naturalmente a vivir en socie$\mathrm{dad}^{50}$; Montesquieu afirma que el hombre ha nacido para vivir en sociedad, y que la ley debe encausarlo por la senda de sus deberes sociales ${ }^{51}$; y Blackstone niega derechamente el contrato social, compartiendo la visión aristotélica del Estado ${ }^{52}$ : más que individualismo, se observa en

\footnotetext{
${ }^{47}$ D’Entrèves (2004), 53; Strauss (1992), 166.

${ }^{48}$ D'Entrèves (2004), 52-57.

${ }^{49}$ D'Entrèves (2004), 57-59.

${ }^{50}$ Locke (2009), 318.

${ }^{51}$ Montesquieu (1972), 52.

${ }^{52}$ Blackstone (2002), 47.
} 
estos autores una concepción de la preeminencia de la persona sobre el estado, por oposición a la preeminencia del estado sobre la persona en Hobbes y Rousseau. Finalmente, el radicalismo del derecho natural moderno se expresaría para D'Entrèves en la concepción del derecho de rebelión, que justificó la Independencia de Estados Unidos y la Revolución Francesa; sin embargo, el propio D'Entrèves afirma que ella hunde sus raíces en el pensamiento medieval ${ }^{53}$.

Según D'Entrèves, el iusnaturalismo moderno no es propiamente una teoría de la ley, sino de los derechos naturales subjetivos, y Hobbes sería el primero en plantear esta posición; pero D'Entrèves observa que Hobbes parece ignorar que derecho objetivo y subjetivo son complementarios, y que, para la mayoría de los iusnaturalistas modernos -inclusive Locke-, "la ley natural era el presupuesto necesario de los derechos naturales" ${ }^{\prime 2}$. Leo Strauss, en cambio, considera que Locke sigue en este punto a Hobbes, y percibe un traslado del énfasis desde las obligaciones a los derechos naturales, donde el individuo deviene centro y origen del universo moral ${ }^{55}$. Sin embargo, debe recordarse que, para Locke, las obligaciones naturales - no voluntarias- existen tanto en el estado de naturaleza como bajo la sociedad política, y que, de ellas, las primeras son la preservación de la existencia propia y de la humanidad, las que coinciden en parte importante con los preceptos primarios de la ley natural en Santo Tomás ${ }^{56}$. Por otra parte, aunque en Cicerón y Santo Tomás no hay propiamente, como en los autores modernos, un desarrollo de los derechos naturales subjetivos con ese nombre ni con la extensión y profundidad de estos últimos, basta leer el Tratado de la Justicia de Santo Tomás para encontrar el derecho a la vida, al honor y otros: es decir, los derechos naturales no sólo son compatibles con su visión del derecho natural, sino que se desprenden necesariamente de sus principios ${ }^{57}$. En realidad, la mayoría de las diferencias entre el derecho natural clásico y el moderno, al menos en autores como Locke (en su Segundo Tratado del Gobierno Civil), Montesquieu y Blacks-

${ }^{53}$ D’Entrèves (2004), 59-60.

${ }^{54}$ D'Entrèves (2004), 61.

${ }^{55}$ Strauss (1992), 248.

${ }^{56}$ Afirma Santo Tomás que los preceptos primarios de la ley natural son conservar la vida individual, conservar la vida de la especie y cultivar la vida específicamente humana (Santo Tomás de Aquino, 1958, 1-2, q.94, a.2, c.).

${ }^{57}$ Para una elaboración del concepto de derechos naturales conforme a la concepción clásica del derecho natural, véase Ugarte (2009). 
tone, proviene principalmente de que el clásico es eminentemente una concepción del orden moral con implicancias políticas, en su mayoría compatibles con el derecho natural moderno, mientras que este último constituye primordialmente una teoría del orden político con presupuestos morales, que generalmente corresponden a los del derecho natural clásico ${ }^{58}$.

Cristopher Wolfe compara lúcidamente el derecho natural clásico con el moderno. Para él, las claves del derecho natural clásico son las siguientes: se trata de una teoría moral objetiva; sus principios son permanentes y universales; se funda en una teoría realista del conocimiento; es expresión de la razón, y no de la voluntad; se basa en la noción de que la razón humana puede alcanzar el bien y los medios conducentes al mismo, sobrepasando el puro placer y el cálculo utilitario; orienta al hombre a la felicidad, aunque implica obligaciones; se centra en el acto humano, pero también enfatiza los hábitos o virtudes; interactúa con una antropología que implica un ordenamiento interno de las facultades humanas y la integración armoniosa de la mente con el cuerpo; y está íntimamente ligada a una teología natural, en que Dios actúa como legislador $^{59}$. A continuación, Wolfe observa un cambio fundamental en el derecho natural moderno: "desde la orientación de la ley natural hacia el cumplimiento positivo de las capacidades de la naturaleza humana - el sumo bien de la virtud-, nos hemos movido a una orientación hacia la evasión del sumo mal, la pérdida de la autopreservación, con las cuestiones acerca de la perfección última del hombre relegadas a una esfera muy privada" ${ }^{60}$. Aunque esta observación es aplicable a algunos iusnaturalistas modernos, no parece atribuible a autores como Locke y Blackstone. Con todo, Wolfe apunta ciertas características que el derecho natural moderno comparte con el clásico: es moralmente objetivo, permanente, universal, generalmente entendido en base a una teoría realista del conocimiento (aunque sus distintos expositores puedan haber tenido diferencias al respecto) y basado en la razón ${ }^{61}$. En realidad, se-

${ }^{58}$ Ashcraft, por ejemplo, afirma que, al distinguir entre un gobernante legítimo y un tirano, al identificar el bien común como fin del gobierno, y al reconocer los orígenes de la autoridad política en el consentimiento del pueblo como entidad corporativa, la teoría de la resistencia o derecho de rebelión de Locke refleja las ideas políticas tradicionales; pero que, simultáneamente, se aleja de las fuentes clásicas y medievales al reconocer los derechos individuales y la igualdad en su ejercicio (Ashcraft, 1999, 230).

${ }^{59}$ Wolfe (2004), 201.

${ }^{60}$ Wolfe (2004), 203.

${ }^{61}$ Wolfe (2004), 204. 
gún hemos revisado anteriormente, los puntos compartidos con el derecho natural clásico por autores como Locke, Montesquieu y Blackstone son incluso mayores: la orientación del hombre hacia la felicidad como fin último, la existencia de obligaciones naturales, la relación íntima con una teología natural en que Dios actúa como legislador, la necesidad de que la ley positiva se adecue a la ley natural, la conformación de un estado limitado y la preeminencia de la persona sobre este último, están también presentes en estos autores.

\section{EI derecho natural en los padres fundadores}

En su primer discurso como presidente de Estados Unidos, George Washington aludió a la ley natural afirmando que una nación no puede prescindir "de las eternas reglas del derecho y la justicia, que el mismo Cielo ha ordenado" 62 . Las siguientes páginas examinan la concepción de esas leyes eternas mencionadas por Washington, considerando las ideas de algunos de los padres fundadores más relevantes y representativos.

\section{A) Samuel Adams}

El derecho natural en Samuel Adams denota la poderosa influencia de Locke, pero también las peculiares condiciones de las colonias norteamericanas. Para Adams, el gobierno y las leyes positivas deben fundarse en "las eternas e inmutables leyes de Dios y la Naturaleza", según las cuales todas las personas tienen derecho a una libertad justa, verdadera, igual e imparcial, tanto espiritual como temporal ${ }^{63}$. Según Adams, la primera ley natural es la autopreservación, que es un deber, sin perjuicio de incluir ciertos derechos que son parte integral del mismo: "primero, el derecho a la vida; segundo, a la libertad; tercero, a la propiedad; junto con el derecho a mantenerlos y defenderlos". Al contrario de Hobbes y Rousseau, Adams sostiene que "es un gran absurdo suponer que, al entrar en sociedad, un hombre o cualquier número de hombres tiene poder para renunciar a sus derechos naturales esenciales o los medios para preservar tales derechos, cuando el gran fin del

\footnotetext{
${ }^{62}$ Dunn (2006), 55.

${ }^{63}$ Adams (2008), 279.
} 
gobierno civil, por la naturaleza misma de su institución, es la mantención, protección y defensa de aquellos derechos"; y si de hecho alguien renuncia a ellos, "la eterna ley de la razón y el gran fin de la sociedad anularían absolutamente tal renuncia" ${ }^{\circ 4}$. Es decir, los derechos naturales son derechos porque su respeto puede exigirse a cualquier persona; pero entrañan adicionalmente la obligación de mantenerlos, lo que Adams estima parte del deber de autopreservación. Para Adams, "cuando los hombres entran en sociedad, es por consentimiento voluntario; y ellos tienen derecho a demandar e insistir en el cumplimiento de las condiciones y limitaciones que integran el equitativo acuerdo original"; pero ello no parece implicar un derecho a automarginarse de toda sociedad, sino a abandonar la actual para acogerse a otra, especialmente ante una "opresión intolerable, civil o religiosa" ${ }^{65}$ : éste sería, como veremos, el sentido en que muchos colonos atribuyeron a la sociedad un carácter consensual.

\section{B) Alexander Hamilton}

Alexander Hamilton, a quien Lord Acton califica como el más capaz de los estadistas americanos ${ }^{66}$, señala que Dios "ha constituido una ley eterna e inmutable, que es indispensablemente obligatoria para toda la humanidad, anterior a cualquier institución humana"; y transcribe un pasaje en que Blackstone afirma que ésta es la llamada "ley natural, la cual, siendo coetánea con la humanidad y dictada por el mismo Dios, es, por cierto, superior en obligatoriedad a cualquier otra. Ella es obligatoria sobre todo el globo, en todos los países, y en todos los tiempos. Ninguna ley tiene validez si es contraria a ella; y las que son válidas, derivan su autoridad, directa o indirectamente, de este original". Para Hamilton, entonces, la ley natural constituye un orden anterior al estado que las instituciones humanas deben respetar, y las leyes positivas son válidas sólo cuando se conforman a él; dicho orden es cognoscible para el hombre, pues Dios lo dotó de la razón para "discernir y seguir aquellas cosas que fueran coherentes con su deber e interés" ${ }^{" 67}$.

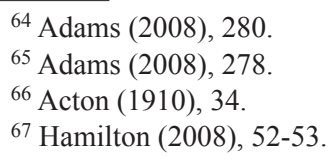


Hamilton critica duramente a Hobbes, sosteniendo que para este último, en el estado de naturaleza, el hombre sería "perfectamente libre de cualquier restricción de la ley o el gobierno. La obligación moral deriva de la introducción de la sociedad civil; y no hay virtud sino la que es puramente artificial, un mero artificio de los políticos para la mantención del orden social" 68 . Hamilton, en cambio, afirma que en un estado de naturaleza existen obligaciones vinculantes para todas las personas, y que "ningún hombre tiene poder moral para privar a otro de su vida, órganos, propiedad, o libertad" ${ }^{69}$. En el fondo, Hamilton critica a Hobbes por no reconocer realidad moral alguna fuera del estado; y, a su juicio, "la razón por la que él tropieza con esta absurda e impía doctrina fue que no creía en la existencia de un principio inteligente y regulador que es el gobernador y será el juez final del universo"; para Hamilton, la aceptación de la existencia de Dios lleva a una conclusión muy distinta, pues "conceder que existe una Inteligencia Suprema que rige el mundo y establece leyes para regular a sus criaturas, y todavía afirmar que el hombre, en un estado de naturaleza, puede considerarse perfectamente libre de todas las restricciones de la ley y el gobierno, parece, para un entendimiento común, irreconciliable"70.

Hamilton sostiene que Dios crea al hombre mediante la ley natural, concediéndole los instrumentos para preservar y beatificar su existencia; y, en uno de sus párrafos más elocuentes, asevera que "los sagrados derechos de la humanidad no necesitan ser hurgados entre viejos pergaminos o en mustios archivos. Ellos están escritos, como con un rayo de sol, en el volumen entero de la naturaleza humana, por la mano de la divinidad misma; y nunca pueden ser borrados u obscurecidos por poder mortal" 71 . Entre estos derechos sagrados está la libertad natural, y Hamilton señala que ningún hombre puede ser privado de ella, porque "es una concesión del beneficioso Creador a toda la raza humana, y la libertad civil está fundada en aquélla, y no puede ser arrancada a ningún pueblo sin la más manifiesta violación de la justicia"; así, la libertad civil "no es una cosa, en su propia naturaleza, precaria y dependiente de la voluntad o el capricho humano, sino conforme a la constitución del hombre, como también necesaria para el bienestar de la sociedad"72.

${ }^{68}$ Hamilton (2008), 51.

${ }^{69}$ Hamilton (2008), 52-53.

${ }^{70}$ Hamilton (2008), 52. En realidad, Hobbes afirma la existencia de Dios, pero no reconoce a sus leyes los atributos que le reconoce Hamilton.

${ }^{71}$ Hamilton (2008), 89.

${ }^{72}$ Hamilton (2008), 70. 


\section{C) Thomas Jefferson}

Thomas Jefferson, descrito por Tocqueville como el más poderoso apóstol de la democracia que jamás haya habido ${ }^{73}$, sostiene que la ley natural es "la ley moral a que el hombre ha sido sujeto por Dios, y de la cual sus sentimientos, o Conciencia, como a veces es llamada, son la evidencia con la cual su Creador lo ha provisto"; y, aunque afirma la existencia inicial de un estado de naturaleza, considera - como Adams y Hamilton- que en él los individuos tienen no sólo derechos, sino también deberes morales que subsisten cuando se constituyen en so$\operatorname{ciedad}^{74}$. Para Jefferson, las leyes positivas deben conformarse a la ley natural, debiendo los legisladores limitarse a "declarar y hacer cumplir sólo nuestros derechos y deberes naturales, y no despojarnos de ninguno de ellos. Ningún hombre tiene un derecho natural para agredir a otro en sus iguales derechos, $\mathrm{y}$ esto es todo lo que las leyes deben prohibirle; cada hombre tiene un deber natural de contribuir a las necesidades de la sociedad, y esto es todo lo que las leyes debieran exigirle"75. Según Jefferson, entonces, el deber natural de preservar la humanidad no se reduce a respetar los iguales derechos de los demás, sino que implica la exigibilidad de actos positivos de contribución al bien común: de hecho, Jefferson - como Montesquieu - considera que las personas son naturalmente sociables: "el hombre fue destinado para la sociedad", y "su moralidad, por tanto, fue formada para este objeto"76.

Para Jefferson, la ley natural guía al hombre hacia un fin determinado, y las personas no hacemos sino obedecer las leyes de nuestro ser "en la fervorosa búsqueda del camino a que ellas nos llaman" "77; según la célebre enunciación de la Declaración de la Independencia que él mismo redactara, ese fin es - como enseña Aristóteles - la felicidad, cuya búsqueda adquiere para Jefferson el carácter de derecho inalienable. No se trata de un derecho a la felicidad, sino a su búsqueda, que implica la libertad de elegir los medios para alcanzarlo conforme a la ley natural, punto en el cual juega un papel fundamental el conocimiento, que según Jefferson es objetivo: por eso señala que "las opiniones y

\footnotetext{
${ }^{73}$ Tocqueville (2006), 261.

${ }^{74}$ Jefferson (1984), 423.

75 Jefferson (1830), 278.

${ }^{76}$ Jefferson (1984), 901.

77 Jefferson (1907), 349.
} 
creencias de los hombres dependen no de su propia voluntad, sino que siguen involuntariamente la evidencia propuesta a sus mentes"78; y, coincidiendo con autores de la Ilustración Escocesa como Hutcheson, afirma la existencia de una conciencia o sentido moral inscrito en la naturaleza de cada hombre, que permite conocer lo correcto y lo incorrecto de modo semejante a como actúan los sentidos externos, y que se entrega en cierto grado a la guía de la razón, pero sólo en aquella parte menor que es estrictamente necesaria ${ }^{79}$. El conocimiento de la ley moral, entonces, "no es abandonado a las débiles y sofísticas investigaciones de la razón, sino que está impreso en los sentidos de todo hombre" $" 80$. Sin embargo, para captar efectivamente las leyes morales, el conocimiento debe ser recto, y por eso Jefferson observa que las verdaderas fuentes de la evidencia son "la cabeza y el corazón de cada hombre racional y honesto" 81 , lo que recuerda "la recta razón congruente con la naturaleza" de que hablaba Cicerón.

También Jefferson critica las doctrinas de Hobbes, señalando que sus principios significan la "humillación de la naturaleza humana; que el sentido de la justicia y la injusticia no deriva de nuestra organización natural, sino que se funda sólo en una convención"; es decir, Jefferson rechaza la idea de que las leyes morales surgen de la convención social, y considera que ellas son anteriores al estado e inmanentes al hombre: "el hombre fue creado para las relaciones sociales; pero las relaciones sociales no pueden mantenerse sin un sentido de justicia; entonces el hombre tiene que haber sido creado con un sentido de justicia" ${ }^{" 2}$. Para Jefferson, los derechos naturales no pueden quedar a merced de las autoridades ni de los consensos sociales; por el contrario, señala que un pueblo libre reclama sus derechos como derivados de la ley natural, y no como una concesión de la autoridad ${ }^{83}$. De este modo, ninguna clase

${ }^{78}$ Jefferson (1984), 346.

79 Jefferson (1984), 901-902. Afirma Samuel Fleischacker que, "en las pocas ocasiones en que Jefferson escribió sobre cuestiones fundamentales de filosofía moral, parece haber identificado claramente sus ideas con la doctrina del sentido moral de Hutcheson y no con las ideas de Hobbes y Locke" (Fleischacker, 2003, 320). Mucho se ha debatido sobre la influencia de la Ilustración Escocesa en los Padres Fundadores, particularmente desde que Gary Wills publicara su libro Inventing America en 1978; aunque a veces se ha exagerado esta influencia, ella parece clara en la concepción de la conciencia o sentido moral en autores como Jefferson y Wilson.

${ }^{80}$ Jefferson (1892-1899), 87.

${ }^{81}$ Jefferson (1984), 423.

82 Jefferson (1830), 278.

${ }^{83}$ Jefferson (1984), 120. 
de gobierno, ni siquiera democrático, puede privar a los hombres de sus derechos naturales, pues entonces devendría tiránico: "la historia nos ha informado que las asambleas de hombres, tanto como los individuos, son susceptibles del espíritu de tiranía"84.

D) James Wilson

George Carey califica las "Lecciones sobre la Ley", de James Wilson, como "el tratamiento más extenso y sistemático de los fundamentos del gobierno entre los padres fundadores" $" 85$. Wilson propone un concepto analógico de ley, distinguiendo leyes divinas y humanas. Entre las divinas, que son obra de Dios, está la ley eterna (en que Dios es ley para sí mismo y para las criaturas), la ley celestial (que gobierna a los ángeles y las almas en el Cielo), la ley natural del universo material, y la ley natural del hombre en su estado actual; esta última, en cuanto promulgada por la razón y la conciencia humanas, se llama propiamente ley natural, y en cuanto promulgada por las Sagradas Escrituras se llama ley revelada. Asimismo, están las leyes humanas, que son obra del hombre y deben basar su autoridad última en las leyes divinas ${ }^{86}$. Por otra parte, Wilson toma el concepto de ley natural de Cicerón, transcribiendo el célebre pasaje en que este último la define como "recta razón congruente con la naturaleza" 87 ; y cita además a Aristóteles, afirmando que el hombre recto es la medida moral de todas las $\operatorname{cosas}^{88}$, idea equivalente a la de Jefferson de que las verdaderas fuentes de la evidencia son "la cabeza y el corazón de cada hombre racional y honesto".

Wilson comenta el concepto de ley de Blackstone, concordando en definirla como una "regla de acción", lo que implicaría que sus destinatarios son susceptibles de dirección, y que su conducta se orienta a un fin determinado: Wilson sigue la tradición aristotélica de la felicidad como fin último del hombre. Pero Wilson discute que la ley deba ser prescrita por un superior: ello sería aplicable sólo a la ley natural —que es prescrita por Dios-, pero no a las leyes humanas, pues la esencial igualdad de las personas no admite tal superioridad; por eso, Wilson

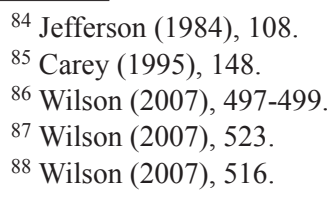


elimina este elemento de la definición blackstoniana de ley humana, afirmando que la verdadera causa de su obligatoriedad es "el consentimiento de aquellos a quienes se aplica la ley". Wilson señala que el Digesto y la Carta Magna discurren sobre esta base, agregando que la costumbre - que en el common law es ley- es evidencia intrínseca del consentimiento de los gobernados, porque es adoptada y mantenida voluntariamente por quienes la acatan ${ }^{89}$.

Por su parte, la causa de la obligatoriedad de la ley natural es la voluntad de Dios. Para Wilson, obedecemos la voluntad de Dios porque es nuestro deber; conocemos que es nuestro deber porque así nos lo dice nuestro sentido moral o conciencia; sabemos que debemos seguir los mandatos de nuestra conciencia porque así lo sentimos. Wilson afirma que la investigación racional no puede sobrepasar este punto, pues la moral, "como las otras ciencias, se funda en verdades que no pueden descubrirse ni probarse por la razón [...] La moral, como las matemáticas, se basa en verdades intuitivas, sin las cuales no podemos avanzar una sola etapa en nuestro razonamiento sobre estas verdades". Posteriormente, este autor describe cómo conocemos nuestros deberes morales y distinguimos el bien del mal: primero, mediante la conciencia o sentido moral, que controla y regula todas las otras facultades humanas y cuyas percepciones superan las ideas de mera utilidad o placer, haciendo evidentes los primeros principios de la moral en que descansa la razón, tal como ésta descansa en los sentidos externos; segundo, mediante la propia razón, que no descubre por sí misma los fines últimos de las acciones humanas ni distingue el bien del mal, sino sólo determina los medios para alcanzar los fines evidentes que le presenta la conciencia, asistiendo, fortaleciendo y aplicando las operaciones de esta última; y, finalmente, mediante la revelación: las Sagradas Escrituras apoyan, confirman y corroboran, pero no reemplazan las operaciones de la conciencia y la razón ${ }^{90}$. Así, Wilson coincide con Jefferson y ciertos autores de la Ilustración Escocesa - como Hutcheson- en la existencia del sentido moral y en sus relaciones con la razón ${ }^{91}$, y por otra parte considera que las verdades alcanzadas mediante la inteligencia natural y las reveladas son perfectamente complementarias, concordando en ello con la mayoría de los padres fundadores.

\footnotetext{
${ }^{89}$ Wilson (2007), 468 y siguientes.

${ }^{90}$ Wilson (2007), 509 y siguientes.

${ }^{91}$ Véase nota 78.
} 


\section{E) Documentos oficiales}

Los padres fundadores son autores de numerosos documentos oficiales, suscritos colectivamente, que recogen el derecho natural como fundamento del orden estatal. Así, el Congreso Continental de Filadelfia, conformado por los diputados de las trece colonias, declaró formalmente en 1774 que los habitantes de las colonias inglesas de Norte América, "por las inmutables leyes de la naturaleza, por los principios de la constitución inglesa, y por distintos fueros o pactos", tenían derecho a la vida, la libertad y la propiedad, y que ellos nunca habían "cedido a poder soberano alguno, el derecho a disponer de cualquiera de ellos sin su consentimiento", agregando que sus indudables derechos y libertades "no pueden serles quitados por ley, ni alterados o disminuidos por poder alguno" 92 . Como observa Carey, lo más notable en esta declaración es la armoniosa combinación de los derechos derivados de la ley natural con aquellos originados en el common law, la Carta Magna y los fueros coloniales ${ }^{93}$.

Por su parte, la Declaración de Derechos de Virginia (1776), el precedente más inmediato de la Declaración de la Independencia, redactada principalmente por George Mason, reconoce que todas las personas son naturalmente libres e independientes y tienen ciertos derechos inherentes como la vida, la libertad, la propiedad, y la búsqueda de su felicidad y seguridad. Afirma asimismo que el fin del gobierno es el bien común, y que la mejor forma de gobierno será siempre aquella que sea más capaz de alcanzarlo. Junto con establecer una forma republicana de gobierno, esta Declaración manifiesta el influjo de Locke por su aceptación del derecho natural y la existencia de ciertos derechos inalienables, por su reconocimiento del origen popular del poder político, el derecho de rebelión, el gobierno representativo y la división de poderes en ejecutivo, legislativo y judicial. El párrafo sobre la libertad religiosa, en cuya redacción participó James Madison, declara el igual derecho de las personas al libre ejercicio de la religión según su conciencia, define la religión como "el deber que todos tenemos hacia nuestro Creador", advierte la obligación de practicar la tolerancia, el amor y la caridad cristianas unos con otros, y reconoce así no sólo la libertad religiosa, sino también la existencia de una obligación moral ante Dios.

\footnotetext{
${ }^{92}$ Journal of the Proceedings (1774), 60.

${ }^{93}$ Carey (1995), 147.
} 
La Declaración de la Independencia de Estados Unidos (1776), redactada por Thomas Jefferson, es probablemente la declaración de derechos más famosa de la historia. Ella comienza con una invocación a "las leyes de la naturaleza y del Dios de la naturaleza", y afirma ciertas verdades que califica de evidentes: "que todos los hombres son creados iguales; que ellos son dotados por su Creador de ciertos derechos inalienables; que entre ellos están la vida, la libertad y la búsqueda de la felicidad; que para asegurar estos derechos se instituyen los gobiernos entre los hombres, derivando sus justos poderes del consentimiento de los gobernados". Es difícil concebir una claridad y síntesis mayores para exponer los principales elementos de la doctrina de los padres fundadores: la ley natural como fundamento del orden político, la esencial igualdad de todos los hombres, la existencia de ciertos derechos inalienables de que las personas han sido dotadas por Dios, la anterioridad ontológica de tales derechos frente a la sociedad política y la obligación de esta última de garantizarlos, el concepto aristotélico de la felicidad como fin del hombre y el derecho a buscarla, el origen popular del poder político, la necesidad del consentimiento de los gobernados y el derecho de rebelión contra el gobierno injusto. Como puede observarse, la terminología de la Declaración de la Independencia está tomada en parte de Locke, pero refleja armónicamente los principios de distintos filósofos y juristas que — según Jefferson- incluyen a Aristóteles, Cicerón, Locke y Sidney ${ }^{94}$.

La Constitución de Massachusetts (1780), la más antigua del mundo entre las constituciones escritas actualmente vigentes, redactada fundamentalmente por John Adams, se inspiró en las ideas de Locke y Montesquieu y en la tradición del puritanismo de Nueva Inglaterra, y tuvo enorme impacto en la teoría constitucional estadounidense al acoger la separación de poderes con contrapesos recíprocos ${ }^{95}$. Esta Constitución define la sociedad política como una asociación voluntaria en que los individuos acuerdan regirse por ciertas leyes para el bien común; tal asociación parece identificarse con la constitución mediante la cual se establece un determinado gobierno, por lo que el contrato social adquiere aquí un matiz menos radical, pues no origina la sociedad en términos absolutos, sino una sociedad en particular sujeta a una forma

\footnotetext{
${ }^{94}$ Dunn (2006), 347.

95 The Federalist (2001), xxx.
} 
de gobierno específica. La Constitución de Massachusetts declara que todos los hombres nacen libres e iguales, y que tienen "ciertos derechos naturales, esenciales e inalienables", como el goce y defensa de la vida, la libertad y la propiedad, y la búsqueda y obtención de su seguridad y felicidad, admitiendo el derecho de rebelión del pueblo de no respetarse el bien común. Como la Declaración de Derechos de Virginia, esta Constitución establece una república, reconociendo que el poder reside originariamente en el pueblo, el derecho al autogobierno y las elecciones libres, la separación de poderes estatales, el carácter responsable de las autoridades políticas como agentes de la comunidad, y el derecho y deber moral de toda persona de dar públicamente culto a Dios según su conciencia.

F) Elementos generales del derecho natural en los padres fundadores

No obstante las naturales diferencias entre John Adams y Thomas Jefferson, James Wilson y James Madison, Samuel Adams y Alexander Hamilton, la concepción del derecho natural como fundamento del orden político en los padres fundadores refleja una notable concordancia en sus elementos principales. Philip Hamburger señala que los colonos americanos redujeron a sus componentes comunes las teorías de distintos autores europeos del derecho natural - como Locke, Blackstone y Pufendorf-, abstrayéndose de ciertos detalles de los tratados extranjeros, y simplificando y generalizando su análisis ${ }^{96}$. Para Hamburger, los padres fundadores entendieron el derecho natural principalmente según la concepción moderna de los "derechos naturales"97; Wolfe coincide con Hamburger, agregando que la figura central para su filosofía política fue Locke, pero estableciendo importantes matices: primero, los padres fundadores no entendieron a Locke y la teoría moderna de los derechos naturales como opuestos a la concepción clásica de la ley natural; segundo, hubo también otras fuentes relevantes, como el constitucionalismo whig, la teología política puritana y la concepción inglesa del common law, esta última con extensas raíces en el pensamiento clásico y medieval, representada por Blackstone y su visión más aristotélica de la sociedad; tercero, los padres fundadores tuvieron general-

\footnotetext{
96 Hamburger (1993), 915.

97 Hamburger (1993), 937-939.
} 
mente una visión profundamente cristiana del orden social, propiciando muchas veces incluso que el propio Estado impulsara el cristianismo; cuarto, fuera de Locke, otros iusnaturalistas modernos fueron también influyentes, como Grocio, Pufendorf, Burlamaqui y Vatel; y quinto, los padres fundadores daban por sentados ciertos elementos del patrimonio clásico y medieval, como el realismo epistemológico ${ }^{98}$.

Sin perjuicio de lo anterior, debe considerarse que, según lo analizado precedentemente, el derecho natural moderno en autores como Locke —en su Segundo Tratado del Gobierno Civil-, Montesquieu y Blackstone admite una lectura substancialmente compatible con el derecho natural clásico, y que muchas de sus principales diferencias son más bien de enfoque. Es por ello precisamente que las obras de los padres fundadores denotan la influencia simultánea de iusnaturalistas modernos y de autores clásicos como Aristóteles, Cicerón y los juristas romanos; en este sentido, Kirk, aún reconociendo la indudable influencia de Locke, considera que los colonos americanos "no fundaron sus principios en un solo filósofo político, sino en lo que ha sido denominada la Gran Tradición, que fluye desde las enseñanzas de los hebreos, clásicos y cristianos, probada posteriormente por la experiencia personal y nacional de sus ancestros británicos y por su propia vida colonial"99, complementada con las teorías de los siglos XVII y XVIII ${ }^{100}$. Según Kirk, los padres fundadores nunca distinguieron con precisión el derecho natural clásico del moderno: por el contrario, el orden norteamericano sería la síntesis armónica de la civilización que a lo largo de la historia se fue centrando sucesivamente en Jerusalén, Atenas, Roma y Londres, para desembocar coherentemente en Filadelfia, donde los padres fundadores concibieron la Declaración de la Independencia y la Constitución de Estados Unidos ${ }^{101}$.

En cuanto a los elementos más relevantes del derecho natural en los padres fundadores, Hamburger destaca los siguientes: primero, la existencia de ciertos derechos naturales en oposición a los derechos adquiridos bajo el gobierno civil; segundo, los derechos naturales se sujetan a la ley natural, que tiene iguales fundamentos que las leyes del mundo físico y constituye una norma moral; tercero, al adoptar una

\footnotetext{
${ }^{98}$ Wolfe (2004), 205 y siguientes.

${ }^{99}$ Kirk (2006), 292.

${ }^{100}$ Kirk (2006), 409.

${ }^{101}$ Kirk (2006), 370.
} 
constitución, las personas entregan algunos de sus derechos al gobierno a cambio de protección para sus derechos irrenunciables, aunque Hamburger reconoce que muchos - como Jefferson y Wilson- sostuvieron que las personas no renuncian a ningún derecho natural al constituirse en sociedad, pues estos se rigen por la ley natural tanto en el estado de naturaleza como en el estado de sociedad; cuarto, las leyes civiles deben reflejar la ley natural como su fundamento moral, especialmente en lo referente a la autopreservación y al deber de no perjudicar a otros en sus iguales derechos; y quinto, no hay tensión o incoherencia en que los derechos naturales sean de algún modo regulados por las leyes civiles, si éstas se conforman a la ley natural ${ }^{102}$.

\section{República democrática y derecho natural en los padres fundadores}

Revisados los principios básicos del derecho natural como fundamento del orden político en los padres fundadores, a continuación se estudiará la forma cómo ellos se reflejan en la república e instituciones democráticas en que culminó el proceso de independencia de Estados Unidos, considerando especialmente el origen, fin y limitaciones del poder político.

\section{A) El origen del poder político}

La necesidad del consentimiento de los gobernados para la legitimidad del gobierno, idea a que aluden permanentemente los padres fundadores, se basa en el hecho de que el poder político reside originariamente en el pueblo, quien lo transmite a las autoridades por él elegidas o aceptadas, en mayor o menor medida, según lo exijan o permitan las circunstancias, pero nunca de modo absoluto, y para ejercerlo siempre conforme al derecho natural. Al definir la ley como una ordenación para el bien común, Santo Tomás señala que tal ordenación corresponde "bien a la comunidad, bien al que hace las veces de ésta. Por tanto, legislar pertenece a la comunidad o a la persona pública que tiene el cuidado de la comunidad, porque, en todo género de cosas, ordenar al fin compete a aquel que tiene como en propiedad ese mismo

102 Hamburger (1993), 908 y siguientes. 
fin" ${ }^{103}$. Tales ideas serían desarrolladas en el siglo XVI por San Roberto Bellarmino y Francisco Suárez, y en el siglo XVII, con las características antes revisadas, por Locke, para luego ser recogidas por los padres fundadores. Así, Jefferson observa que, "por la naturaleza de las cosas, cada sociedad debe siempre poseer en sí misma el poder soberano de legislar" 104 , y en la Declaración de la Independencia afirma que los gobiernos derivan "sus justos poderes del consentimiento de los gobernados"; debe tenerse presente que Jefferson habla sólo de "justos poderes", es decir, el pueblo transmite al gobierno sólo los poderes que son legítimos en orden a cumplir su fin natural, y no poderes ilimitados como sostienen Hobbes y Rousseau ${ }^{105}$. El Preámbulo de la Constitución de Estados Unidos refleja con admirable fuerza la doctrina de que el poder político reside originariamente en el pueblo: "Nosotros, el Pueblo de los Estados Unidos, en orden a formar una Unión más perfecta, establecer Justicia, asegurar la Tranquilidad doméstica, proveer a la defensa común, promover el Bienestar general, y asegurar las Bendiciones de la Libertad para nosotros mismos y nuestra Posteridad, ordenamos y establecemos esta Constitución para los Estados Unidos de América".

Suárez explica los fundamentos filosóficos del origen popular del poder político afirmando que, por la naturaleza de las cosas, todas las personas nacen libres, y ninguna tiene jurisdicción política ni dominio sobre otra, no habiendo razón alguna para atribuir originariamente el poder político a unas personas sobre las demás; ahora bien, no puede concebirse una comunidad política sin un poder común que sus miembros individuales deban obedecer; y si este poder no reside en ningún individuo ni grupo particular, debe necesariamente existir en la comunidad como un todo ${ }^{106}$. Esta doctrina adquiere posteriormente en Locke, como hemos visto, un acentuado matiz contractualista: siendo todas las personas naturalmente libres, iguales e independientes, ninguna puede someterse al poder político sin su consentimiento, y el único modo de hacerlo es mediante un acuerdo con otras personas, en que todas se

${ }^{103}$ Santo Tomás de Aquino (1958), 1-2, q. 90 a 3, 40.

104 Jefferson (1984), 118.

105 Austin Fagothey afirma que el lenguaje de Jefferson resume la doctrina de Bellarmino y Suárez, aunque estos no usaran exactamente las mismas palabras (Fagothey, 2000, 399).

${ }^{106}$ Suárez (1967), libro III, capítulo II, párrafos 3 y 4. 
unen formando una comunidad ${ }^{107}$. Entre los padres fundadores, quien mejor explica su concepción del origen del poder político es Wilson: "todos los hombres son, por naturaleza, iguales y libres: ninguno tiene derecho a autoridad alguna sobre otro sin su consentimiento: todo gobierno legítimo se funda en el consentimiento de aquellos que están sujetos a él: tal consentimiento fue dado en vistas a asegurar e incrementar la felicidad de los gobernados"108. Por otra parte, Wilson reconoce que el hombre es por naturaleza sociable y que debe integrarse necesariamente a una sociedad, lo que tiene lugar mediante dos acuerdos fundamentales: por el primero se forma la sociedad política, y cada individuo conviene unirse con todos los otros para el bien común, a cambio del compromiso recíproco de darse protección, defensa y seguridad; y por el segundo acuerdo se forma el gobierno político al que la sociedad así formada debe sujetarse ${ }^{109}$.

Para los padres fundadores, el hombre es naturalmente sociable y sus facultades intelectuales lo ordenan a la vida social; pero si la sociedad humana es una institución natural y necesaria para las personas, ¿para qué se requeriría su consentimiento? Esta aparente contradicción de los padres fundadores se resuelve a mi juicio del siguiente modo: existe en primer lugar una sociedad universal que incluye a toda la humanidad, la cual no requiere del consentimiento de las personas para formarse, pues está inscrita en la naturaleza misma de todas ellas, y que es causa de la obligación natural de preservar la especie a que aluden Santo Tomás y Locke; pero, adicionalmente, existen las sociedades políticas concretas, sujetas a un gobierno determinado: no obstante que las personas tienden naturalmente a organizarlas, su formación sí requiere del consentimiento de los gobernados, pues sólo así puede superarse la mera reunión física de personas y lograrse su ordenación al bien común, que es el sello distintivo de toda sociedad política. Sin embargo, como asevera Rafael Fernández Concha, ello no significa que la sociedad política quede sujeta sólo a leyes dictadas por el arbitrio de los gobernados, porque la sociedad política es una institución natural y está por

${ }^{107}$ Locke (2009), 330-331. Para Kirk, los padres fundadores no adhirieron a la teoría abstracta del contrato social, sino que simplemente siguieron una realidad institucional experimentada por las propias colonias: el gobierno representativo en la tradición inglesa (Kirk, 2006, 420).

${ }^{108}$ Wilson (2007), 4.

${ }^{109}$ Wilson (2007), 553-554. 
tanto sujeta a leyes naturales ${ }^{110}$; pero las personas no están obligadas a integrarse a una sociedad política específica, y nada puede impedirles abandonar su actual sociedad para integrarse a otra, salvo que estén sujetas a obligaciones morales que la expatriación haga imposibles o muy difíciles de cumplir: de hecho, los padres fundadores reconocen un derecho natural de expatriación ${ }^{111}$.

Esta interpretación del pensamiento de los padres fundadores se confirma al considerarse el origen histórico de las colonias norteamericanas de Nueva Inglaterra: los peregrinos del Mayflower abandonaron una Inglaterra que les parecía corrompida para formar en América una sociedad más acorde a los principios de la religión; y al desembarcar en Plymouth en 1620, es decir, mucho antes de publicarse las obras de Hobbes y Locke, concluyeron un acuerdo expreso - citado por James Wilson al tratar del origen de la sociedad política - ${ }^{112}$ en que, invocando a Dios, y en su calidad de leales súbditos de Jacobo I, pactaron solemnemente unirse en un cuerpo político para su mejor orden y preservación, obligándose a promulgar leyes justas y equitativas según fuera más conveniente para el bien general de la colonia, a las cuales prometieron la debida sujeción y obediencia. Posteriormente, conforme fueron surgiendo diferentes sectas entre los colonos, sus seguidores fueron fundando nuevos poblados — nuevas sociedades - por todo el noreste del continente.

B) El fin de la sociedad política

Para los padres fundadores, el fin del Estado o sociedad política es el bien común, que implica tanto el bien general de la comunidad

${ }^{110}$ Fernández Concha (1965), 171-172. Fernández Concha señala que la sociedad "no es un mero agregado de personas, sino un compuesto moral de éstas, resultante del vínculo que ordena sus acciones al conseguimiento del bien común; y que, por tanto, no ha de considerarse causa de la sociedad civil ningún hecho que reúna o junte a varios o muchos individuos en un mismo espacio sin establecer entre ellos la obligación de conspirar por un mismo fin": la mera propagación de las familias, la prepotencia de un conquistador o el advenimiento de colonos o peregrinos no originan por sí solos una nueva sociedad. El único hecho adecuado a formar un estado, esto es, la unión no sólo material, sino también moral de personas, es "el mutuo y universal consentimiento de los fundadores", que puede ser anterior, coetáneo o posterior a la reunión física, expreso o tácito, e incluso obligatorio, como cuando la reunión de personas se ha formado paulatinamente de modo que ya no puedan seguir viviendo juntas sin un gobierno común.

111 Jefferson (1984), 346.

112 Wilson (2007), 782. 
como el de las personas en particular. Así, la Declaración de Derechos de Virginia dice que el gobierno se establece "para el beneficio, protección y seguridad común del pueblo, nación o comunidad"; y la Constitución de Massachusetts declara que las personas se constituyen en sociedad mediante un pacto en que acuerdan ser regidas por ciertas leyes “para el bien común”. La Declaración de la Independencia, por su parte, enfatiza que los gobiernos se establecen para asegurar los iguales derechos de que las personas han sido dotadas por su Creador, como la vida, la libertad y la búsqueda de la felicidad; pero ello no obsta a que el gobierno, junto con asegurar tales derechos, reconozca como su fin el bien de la comunidad como conjunto. La importancia que para los padres fundadores tiene el bien común se refleja en la célebre crítica de Madison a las facciones, que en el fondo se relaciona con la necesidad de prevenir distorsiones al bien común como fin de la sociedad política: Madison define las facciones como un número de ciudadanos, sean mayoría o minoría, que se unen y actúan por una pasión o interés común, adverso a los derechos de otros ciudadanos o a los intereses permanentes de la comunidad, provocando que las decisiones gubernamentales se tomen considerando la fuerza superior de una mayoría interesada y abusadora, y no conforme a las reglas de justicia y a los derechos de la minoría. Particularmente cuando se constituyen en mayoría, las facciones adquieren la capacidad de sacrificar a sus pasiones e intereses "tanto el bien público como los derechos de otros ciudadanos", y de ahí la necesidad de prevenirlas ${ }^{113}$.

Respecto del fin del gobierno, una de las polémicas más interesantes entre los padres fundadores, y que retrata su concepción de los derechos naturales, se refiere a la necesidad de enumerar en la constitución ciertos derechos y libertades esenciales, anteriores al Estado y que éste debe garantizar (un Bill of Rights). Para Hamilton, tales enumeraciones sólo pueden entenderse como estipulaciones entre el rey y sus súbditos (como la Carta Magna), en que aquél asegura a estos el respeto de sus derechos; pero no tienen sentido para constituciones como la estadounidense, fundada en el poder del pueblo y ejecutada por sus "representantes y sirvientes inmediatos"; en rigor, el pueblo retiene todos sus derechos naturales y no renuncia a ninguno, no habiendo entonces

113 The Federalist 10 (2001), 42-45. Observa Carey que las ideas de "justicia", "derechos de otros ciudadanos" e "intereses permanentes de la sociedad" tienen para Madison un valor moral objetivo (Carey, 1995, 41). 
razón para exigir a los gobernantes una garantía expresa de respeto a tales derechos: según Hamilton, carece de objeto prohibir al gobierno que viole los derechos esenciales cuando nadie le ha otorgado poder para hacerlo ${ }^{114}$. Para Wilson, un Bill of Rights es adicionalmente imprudente, pues podría originar la presunción de que los derechos no enumerados hubieran sido renunciados ${ }^{115}$. Pero otros padres fundadores, aún concordando en el carácter inviolable de los derechos esenciales, fueron partidarios del Bill of Rights: para Jefferson, sus principales beneficios son que implica otorgar al poder judicial la facultad de revisar su debido respeto; permite a las personas defenderse de los abusos del gobierno; si bien es imposible enumerar todos los derechos esenciales, incluir algunos es mejor que ninguno; y, aunque el Bill of Rights no necesariamente es eficaz en todas las circunstancias, tampoco es ineficaz, y siempre tiene mucha fuerza ${ }^{116}$. Aunque la Constitución original no incluyó un Bill of Rights, éste se introdujo mediante la primera enmienda constitucional bajo la redacción de Madison.

En este contexto, el derecho natural de rebelión del pueblo contra el gobierno injusto es una consecuencia lógica de que los padres fundadores consideraran el bien común como fin de la sociedad política, y fue reconocido no sólo por autores individuales, sino también por documentos oficiales, como la Declaración de Derechos de Virginia, la Constitución de Massachusetts y, ciertamente, la Declaración de la Independencia, cuyo propósito formal fue publicar los fundamentos filosóficos y políticos de la independencia norteamericana: cuando cualquier forma de gobierno se hace destructiva de sus fines propios, el pueblo tiene el derecho de alterarlo o abolirlo, y de "instituir un nuevo gobierno, estableciendo sus fundamentos en los principios y organizando sus poderes en la forma que le parezcan más viables para obtener su seguridad y felicidad". La universalidad atribuida por los padres fundadores al derecho de rebelión queda de manifiesto al expresar Hamilton que los pueblos sometidos a un gobierno despótico "tienen un derecho inherente para, cuando sea que quieran, sacudir el yugo de la servidumbre (incluso habiendo sido sancionado por el uso inmemorial de sus ancestros), y modelar su gobierno bajo los principios de la libertad

\footnotetext{
114 The Federalist 84 (2001), 445.

115 Wilson (2007), 195.

116 Jefferson (1984), 943.
} 
civil"117. Así, los padres fundadores adhirieron a una tradición medieval, presente en autores como Santo Tomás, los escolásticos españoles del siglo XVI - como Suárez-y en exponentes del derecho natural moderno — como Locke—; por eso dice D'Entrèves que, en este punto, la Declaración de la Independencia recuerda más las declaraciones de los juristas y filósofos medievales que las especulaciones abstractas de los teóricos del derecho natural moderno ${ }^{118}$.

C) Un gobierno limitado

Según los padres fundadores, existe un orden natural que debe reflejarse en el orden político, en virtud del cual las personas tienen ciertos atributos esenciales de que la sociedad civil no puede despojarlas. Para Madison, la precedencia del orden natural sobre el político se refleja "tanto en materia de tiempo como en grado de obligatoriedad", en términos que, antes de ser reconocidas como miembros de la sociedad política, las personas deben considerarse "como sujetas al Gobernador del Universo"119. Así, incluso el pueblo actuando en forma soberana debe regirse por la ley natural, y por eso John Quincy Adams opina que el principio de que "la nación completa tiene derecho para hacer cualquier cosa que le plazca, no puede en sentido alguno ser admitido como verdadero", porque "las eternas e inmutables leyes de la justicia y la moral son primordiales para toda legislación humana": para Quincy Adams, el pueblo tiene el "poder", pero no el "derecho" de violar tales normas, y sostener que la mayoría no está obligada por ley humana o divina y que no está sujeta a otra regla que a su soberana voluntad, implicaría que no hay seguridad posible para los ciudadanos y sus derechos inalienables, originando una espantosa forma de despotismo bajo la apariencia exterior de una democracia ${ }^{120}$. Es por ello que, según Samuel Adams, el poder legislativo "no tiene derecho a un poder absoluto y arbitrario sobre las vidas y fortunas de las personas; ni los mortales pueden asumir una prerrogativa no sólo demasiado alta para los hombres, sino incluso para los ángeles, y por tanto reservada para la sola Deidad"121. No basta, entonces, con que las leyes sean pro-

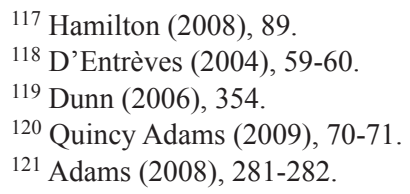


mulgadas por el pueblo actuando en forma soberana en una república democrática, sino que deben conformarse a la ley natural, respetar los derechos esenciales de las personas y dirigirse al bien común; de lo contrario, se tratará de leyes tiránicas, pues - como afirmaron los revisores de un anteproyecto de Constitución de Massachusetts - también "un tirano puede gobernar mediante leyes" 122 .

La conciencia de la imperfección y límites de cualquier forma de gobierno, inclusive la república democrática por ellos instituida, es un rasgo distintivo del pensamiento de los padres fundadores, que en este punto siguen a Montesquieu. Efectivamente, para Montesquieu, la democracia no asegura por sí misma la libertad política, pues ésta sólo existe en los gobiernos moderados; y sólo aparece en ellos cuando no se abusa del poder, siendo "una experiencia eterna, que todo hombre que tiene poder siente la inclinación de abusar de él, yendo hasta donde encuentra límites": de ahí su célebre doctrina de que, "para que no se pueda abusar del poder es preciso que, por la disposición de las cosas, el poder frene al poder" ${ }^{\prime 23}$. Es decir, también la democracia puede ser abusiva, y por eso Madison comenta que no hay forma de gobierno humano que pueda ser perfecta, y que "aquel gobierno que es el menos imperfecto es por tanto el mejor gobierno; los abusos de todas las otras formas de gobierno han llevado a preferir el gobierno republicano como el mejor de todos los gobiernos, por ser el menos imperfecto" ${ }^{124}$. Siguiendo a Montesquieu, Madison afirma que "la acumulación de los poderes legislativo, ejecutivo y judicial, en las mismas manos, ya sean de uno, unos pocos o muchos, y ya sean hereditarias, autodesignadas o electivas, puede justamente señalarse como la definición misma de la tiranía": como pensaba Locke, la tiranía no es privativa de la monarquía, y también puede darse en la democracia. Precisamente para evitar los abusos del gobierno, asegurar la preeminencia de la persona y sus derechos naturales, e impedir lo que Tocqueville llamaría la "tiranía de la mayoría" 125 , los padres fundadores instituyeron no una democracia totalitaria, sino una república democrática cuya principal característica es la desconcentración del poder, y entre los medios a que acudieron para lograrlo están la separación y control recíproco de los poderes eje-

\footnotetext{
122 Parsons (1859), 366.

${ }^{123}$ Montesquieu (1972), 150.

${ }^{124}$ Dunn (2006), 443.

125 Tocqueville (2006).
} 
cutivo, legislativo y judicial, la división del poder legislativo en Senado y Cámara de Representantes, la revisión de la constitucionalidad de los actos del ejecutivo y el legislativo por la Corte Suprema, la facultad del presidente de Estados Unidos de vetar las leyes, la acotada duración de los cargos electivos, y la limitación al poder central mediante las facultades reservadas a cada estado por el sistema federal, que Lord Acton consideraba el control natural sobre la democracia absoluta en Estados Unidos $^{126}$.

D) Esclavitud y discriminación racial

La coherencia de los padres fundadores se ve empañada por el hecho de no haber abolido la esclavitud, sin perjuicio de lo cual es interesante notar que, cuando Abraham Lincoln luchó posteriormente por abolirla, acudió expresamente a su legado. En 1858, Lincoln sostuvo unos célebres debates con Stephen Douglas, para quien, en virtud de la soberanía popular, la nación tiene derecho para decidir si permitir o no la esclavitud, a su sola elección; de hecho, Douglas negó deliberadamente la existencia de una justicia natural a la cual debe adecuarse el orden político, aduciendo que no cabe argumentar que la esclavitud es intrínsecamente mala, y que entonces no puede tolerarse: "ustedes deben permitir al pueblo decidir por sí mismo si la esclavitud es un bien o un mal"127. Por el contrario, Lincoln acudió expresamente al derecho natural y a las ideas de los padres fundadores, considerando que no hay razón alguna para sostener que las personas de raza negra no tienen "todos los derechos naturales enumerados en la Declaración de la Independencia, el derecho a la vida, a la libertad, a la búsqueda de la felicidad", al igual que las personas de raza blanca ${ }^{128}$. Para Lincoln, como para los padres fundadores, la soberanía popular no permite aprobar cualquier cosa — en este caso, la esclavitud—, sino que debe siempre respetar los derechos inherentes a la naturaleza humana.

Mediando el siglo XX, también Martin Luther King defendió los iguales derechos de las personas de raza negra contra la discriminación y segregación racial, apoyándose en la Constitución y la Declaración de

126 Acton (1910), 37. Sobre los métodos de desconcentración del poder, véase Carey (1995).

127 The Lincoln-Douglas Debate (2008), 24-28.

${ }^{128}$ The Lincoln-Douglas Debate (2008), 52. 
la Independencia, y aduciendo que los padres fundadores constituyeron una promesa de que a todos los hombres, tanto negros como blancos, "les serían garantizados sus derechos inalienables a la vida, la libertad y la búsqueda de la felicidad"129. Para King, las leyes positivas deben ser justas, y existe un derecho natural de rebelión contra las injustas: "yo sería el primero en abogar por el obedecimiento de las leyes justas. Uno tiene no sólo una responsabilidad legal, sino también moral de obedecer las leyes justas. Por el contrario, uno tiene la responsabilidad moral de no obedecer las leyes injustas. Compartiría con San Agustín que una ley injusta no es en modo alguno una ley". Para distinguir entre leyes justas e injustas, Martin Luther King se basa en la ley natural, siguiendo expresamente a Santo Tomás: "una ley justa es un código hecho por el hombre que concuerda con la ley moral o ley de Dios. Una ley injusta es un código que no armoniza con la ley moral. Para ponerlo en los términos de Santo Tomás de Aquino: una ley injusta es una ley humana que no está enraizada en la ley eterna y en la ley natural. Cualquier ley que eleva la personalidad humana es justa. Cualquier ley que degrada la personalidad humana es injusta" 130 . Así, las ideas de King reflejan una substancial armonía entre el derecho natural clásico en Santo Tomás y el moderno en los padres fundadores.

\section{Conclusiones}

En conclusión, puede decirse que la ley natural constituye para los padres fundadores un orden moral objetivo, de origen divino, inmutable y universalmente vinculante, que por estar impreso en la naturaleza misma de las cosas implica la existencia de verdades evidentes, y que es siempre cognoscible válidamente por cualquier persona mediante su sola inteligencia natural, sin perjuicio de su compatibilidad con la revelación cristiana. En virtud de esta ley, las personas son esencialmente iguales y tienen ciertos derechos naturales irrenunciables de que nadie puede privarlas, como la vida, la libertad y la propiedad, estando asimismo sujetas a obligaciones morales no voluntarias, entre ellas la preservación de la existencia propia y de la humanidad. Aunque las personas son naturalmente sociables, ellas viven inicialmente en un estado de naturaleza en que la ley natural tiene perfecta vigencia, inclu-

\footnotetext{
${ }^{129}$ Martin Luther King (1991), 217.

${ }^{130}$ Martin Luther King (1991), 293.
} 
yendo todos los derechos y obligaciones que ella origina; sin embargo, mediante un contrato social, las personas ponen fin al estado de naturaleza y conforman una sociedad política en que la ley natural mantiene plena eficacia. Este contrato social no parece originar la sociedad en términos absolutos - ello sería incompatible con la natural sociabilidad humana-, sino una sociedad determinada que se acoge a una forma de gobierno específica mediante el consentimiento de los gobernados.

La concepción del derecho natural de los padres fundadores constituye la síntesis armoniosa de diversas fuentes, entre ellas, autores de la Antigüedad Clásica como Aristóteles y Cicerón; la tradición política medieval, especialmente en lo referente al origen popular del poder político y al derecho de rebelión; la experiencia del autogobierno de los colonos norteamericanos y el sistema representativo de raigambre whig; el cristianismo y, especialmente, el puritanismo de Nueva Inglaterra; la moderna teoría de los derechos naturales de Locke y otros autores como Grocio, Pufendorf, Burlamaqui y Vatel; el constitucionalismo de Montesquieu, y la tradición del common law representada por Blackstone. Todo este acervo, enriquecido por el genio de hombres como Jefferson, Hamilton, Madison, Adams y Wilson, culminó con la institución de una república democrática que, según los padres fundadores, debe respetar el orden natural, que es anterior a la sociedad política, considerando el fin del hombre, que es la felicidad, y el fin de la sociedad política, que es el bien común. El gobierno y las leyes positivas deben estar siempre informados por estos elementos, que reflejan la preeminencia de la persona y sus derechos naturales sobre el orden político; de hecho, puede decirse que prácticamente todas las medidas adoptadas por los padres fundadores tuvieron por fin, directa o indirectamente, asegurar el respeto de este principio, y por ello precisamente limitaron el poder político mediante su desconcentración en un sistema constitucional de equilibrios y contrapesos recíprocos.

\section{REFERENCIAS BIBLIOGRÁFICAS}

Acton, John Emerich Edward Dalberg-Acton, Barón: Lectures on the French Revolution. Macmillan and Co., Limited, 1910.

Adams, John Quincy: Writings of John Quincy Adams, Volume I. Biblio Life LLC, 2009.

Adams, Samuel: The Writings of Samuel Adams. Biblio Bazaar LLC, 2008.

Aquino, Santo Tomás de: Suma Teológica, Tomo VI. Biblioteca de Autores Cristianos, 1958. 
Ashcraft, Richard: Locke's Political Philosophy, en The Cambridge Companion to Locke (edición de Vere Chappell). Cambridge University Press, 1999.

Blackstone, William: Commentaries on the Laws of England, Volume I: Of the Rights of Persons. The University of Chicago Press, 2002.

Carey, George: In Defense of the Constitution. Liberty Fund, Inc., 1995.

Cicerón, Marco Tulio: Obras (Edición Lefebvre). París, 1823. Traducción de José Joaquín Ugarte Godoy en "El Iusnaturalismo: Necesidad de una Fundamentación Metafísica y Antropológica. Con Referencia a las Ideas de John Finnis”. Anuario de Filosofia Jurídica y Social, Ponencias, Buenos Aires, 2005.

D'Entrèves, Alexander Paserin: Natural Law: An Introduction to Legal Philosophy. Transaction Publishers, 1994.

Dunn, Susan: The Essential Writings of the Founding Fathers. Basic Books, 2006.

Fagothey, Austin: Right and Reason. Tan Books and Publishers, Inc., 2000.

Fernández Concha, Rafael: Filosofía del Derecho, Tomo II. Editorial Jurídica de Chile, 1965.

Fleischacker, Samuel: The Impact on America: Scottish Philosophy and the American Founding, en The Cambridge Companion to Scottish Enlightment (edición de Alexander Broadie). Cambridge University Press, 2003.

Hamburger, Philip: "Natural Rights, Natural Law, and American Constitutions". The Yale Law Journal, Vol. 102, 1993.

Hamilton, Alexander: The Revolutionary Writings of Alexander Hamilton (edición de Richard Vernier). Liberty Fund, Inc., 2008.

Hobbes, Thomas: Leviatan. Fondo de Cultura Económica, 1992.

Jefferson, Thomas: The Writings of Thomas Jefferson, Volume IV (edición de Thomas Jefferson Randolph). Gray and Bowen, 1830.

: The Writings of Thomas Jefferson, Volume XVI. The Thomas Jefferson Memorial Association of the United States, 1907.

: The Writings of Thomas Jefferson (edición de Paul Leicester Ford). 18921899.

-: Writings (edición de Merrill Peterson). The Library of America, 1984.

Journal of the Proceedings of the Congress, Held at Philadelphia. William and Thomas Bradford, London Coffee House, 1774.

King, Martin Luther: A Testament of Hope. The Essential Writings of Martin Luther King $J r$. (edición de James Washington). Harper One, 1991.

Kirk, Russell: The Roots of American Order. ISI Books, 2006.

Locke, John: Two Treatises of Government (edición de Peter Laslett). Cambridge University Press, 2009.

Montesquieu, Charles de Secondat, Barón de: Del Espíritu de las Leyes. Editorial Tecnos, 1972.

Parsons, Theophilus: Memoir of Theophilus Parsons. Ticknor and Fields, 1859.

Rousseau, Jean Jacques: El Contrato Social. SARPE, 1983.

Schneewind, J. B.: Locke's Moral Philosophy, en The Cambridge Companion to Locke (edición de Vere Chappell). Cambridge University Press, 1999.

Strauss, Leo: Natural Right and History. The University of Chicago Press, 1992.

Suárez, Francisco: De legibus ac Deo legislatore. Instituto de Estudios Políticos, 1967.

The Federalist. Reedición de la Gideon Edition a cargo de George Carey y James McClellan). Liberty Fund, Inc., 2001). 
The Lincoln-Douglas Debates. Edición de Robert Johannsen. Oxford University Press, 2008.

Tocqueville, Alexis de: Democracy in America (edición de J. P. Mayer). Harper Collins, 2006.

Ugarte Godoy, José Joaquín: "El Iusnaturalismo: Necesidad de una Fundamentación Metafísica y Antropológica. Con Referencia a las Ideas de John Finnis”. Anuario de Filosofia Jurídica y Social, Ponencias. Buenos Aires, 2005.

-: "La Necesaria Fundamentación en Dios de los Derechos Naturales o Derechos Humanos". Quintas Jornadas de Derecho Natural Chileno Argentinas, 2009, en vías de publicación.

Wilson, James: Collected Works of James Wilson (edición de Kermit Hall y Mark Hall). Liberty Fund, Inc., 2007.

Wolfe, Christopher: "Thomistic Natural Law and the American Natural Law Tradition". En John Goyette, Mark Latkovic y Richard Myers (eds.), St. Thomas Aquinas and the Natural Law Tradition: Contemporary Perspectives. The Catholic University of America Press, 2004.

Recibido: junio 2009. Aceptado: mayo 2010. 